\title{
Javanese Ethnic Non-verbal Language Forms and Functions, an Ethnopragmatic Study for Education
}

\author{
Pranowo $^{1}$, R P Dewi ${ }^{2}$ \\ \{1prof.pranowo2@gmail.com, ${ }^{2}$ budimanrishe@usd.ac.id $\}$ \\ ${ }^{1,2}$ Universitas Sanata Dharma, Yogyakarta, Indonesia
}

\begin{abstract}
Nonverbal language is a language that is expressed without using words. This article specifically deals with the forms and functions of ethnic Javanese nonverbal language. Nonverbal languages are divided into two, namely dynamic nonverbal language and static nonverbal language. This study was conducted using the ethnopragmatic approach for education. The form of dynamic nonverbal language encompasses the entire body and its parts and movements, and static nonverbal language in the form of the whole body and its parts which are perceived subjectively by the hearer. Dynamic nonverbal language forms include head nods, eye gazes, facial expressions, lip movements, hand movements, elbow movements, finger movements, and handshakes. Meanwhile, the forms of static nonverbal languages include the shape of the lips, the cheeks, the teeth, the nose, the eyeball, hair color, posture, skin color, etc. Dynamic nonverbal language functions are different from the functions of static nonverbal language. Dynamic nonverbal language functions are determined by speakers, while nonverbal static language functions depend on the hearer's perception and understanding..
\end{abstract}

Keywords: Dynamic Nonverbal Language, Static Nonverbal Language, Ethnopragmatic Approach

\section{INTRODUCTION}

Nonverbal language is a language without words [1]. Javanese ethnic nonverbal language consists of hundreds of forms and functions. In this article, however, only a few can be identified. As a language without words, nonverbal language can be identified as follows: (a) language without words that can stand alone, (b) language without words as the context of verbal language, and (c) language without words as a determinant of social status. In certain situations, nonverbal language can stand alone to communicate with others, such as using gestures, signals, signs, symbols, motion, gaze, eye contact, shake or nod of the head, body movement, facial expressions, body posture, skin colour, nose shape, costume, hairstyle, and proxemics. Nonverbal language as the context of spoken verbal language can clarify communication of spoken language, such as saying the word "yes" while nodding your head, or saying the phrase "come here!" while moving your palm down the hearer.

Nonverbal language can also be a determinant of social status revealed through various manifestations, such as architectural design, home decor, paralanguage, make-up, concept of time, status in the society (including pangkat = rank, derajat = social status, and semat = wealth), 
and symbols in the society (including turangga $=$ horse symbolizing vehicles, $k u k i l a=$ domestic birds symbolizing pets, and wanodya = women as wives), etc. [2].

In addition to the forms above, the communicative functions of the nonverbal language can be identified. Discussing non-verbal language that stands alone or as a context in a spoken verbal language can function to express various speaker's meanings, such as affirmation, rejection, agreement, orders, invitations, etc. in accordance with the ideas and feelings of the speaker. Perceived as a social status, nonverbal language can be in the form of metaphorical symbols that abound in the society.

Nonverbal language is a language without words. The form and function of nonverbal language can be divided into two, namely dynamic nonverbal language and static nonverbal language [3]. Dynamic nonverbal language is the nonverbal language of the body and parts of the body that are moved to convey the message of the speaker to the hearer. Body and limb movements (kinesics) can send messages to hearers, such as (1) showing the attitude of the speaker to the hearer, (2) describing the emotional condition of the speaker to the hearer, and (3) controlling the environment so that the situation is conducive (regulatory), (4) affirming the wishes of speakers to the hearers, etc. [4]. Static nonverbal languages can be in the form of the speaker's body language, gestures, and objects [5]

Although the study of nonverbal language has not been as much as that of the verbal language, nonverbal language actually has a very extensive function in communication. Every person who speaks verbal language, 93\% always uses nonverbal language [1], [6]. This is natural because nonverbal language was used long before verbal language. In fact, after the emergence of verbal language, the habit of using nonverbal language still continues until today.

This fact encourages the writer to study nonverbal languages in an interdisciplinary manner using the ethnopragmatic theory, combining ethnography and pragmatics. Ethnography is a cultural study that describes the life of a particular society which includes cultural knowledge, cultural behaviour, and artefacts [7]. That way, the use of nonverbal language is a cultural behaviour, meaning that every nonverbal language is a cultural behavior of a society. The purpose of ethnographic studies is to describe and analyse the culture of a society to understand the relationship between language and the cultural context in the daily life [8].

With the ethnopragmatic theory, the study of nonverbal languages can include stand-alone nonverbal language, nonverbal language as the context of verbal language, and nonverbal language as determinants of social status. However, this article will only examine one aspect, namely the stand-alone nonverbal language seen from its context and communicative functions based on contexts.

The context referred to in the pragmatic study is "... aspects of the state of use of the actual language which is considered relevant to the meaning". In other words, the context is the schematic construction to achieve the pragmatic meanings that have a matching code of linguistic elements with schematic elements. However, the context is actually only a form of "world knowledge" understood by speakers and hearers [9], [10].

The ethnopragmatic study is a study of the use of language based on the context and cultural background of the speech community. On the basis of that approach, the problem is "what forms and types of nonverbal languages are commonly used by the Javanese people in communication?"

\section{RESEARCH METHOD}

This research is a qualitative descriptive study [9], involving the Javanese society as the research subject. The data are forms and types of nonverbal languages supported by contexts. 
The data was collected by participatory observation techniques, interviews with speakers, and recording. The researcher observed the Javanese people whose first language is the Javanese language and speak Indonesian as a second language. The researcher also conducted interviews with several informants to confirm the messages delivered using nonverbal language. To support data collection, researchers also used audio-visual recording in addition to observations. Because the researcher is of the Javanese ethnicity, the research instrument is the researcher himself with his understanding of Javanese language and culture. The collected data is then analysed in the following steps (1) identifying data, (2) classifying data, and (3) interpreting messages contained in the research data.

\section{RESULT AND DISCUSSION}

Nonverbal languages are all languages that do not contain words. The form of nonverbal language can be in the form of body and parts of the human body, symbols and their interpretations, signs and their interpretations, nuances and their interpretations, etc. Meanwhile, types of nonverbal languages can be divided into two, namely dynamic and static nonverbal languages [11]. Dynamic nonverbal languages are nonverbal languages that are movable, can be moved, produce sound when used in communication. The whole body and its parts that are moved to communicate are the dynamic types of nonverbal language. Subsequently, dynamic nonverbal languages can be described as follows.

Nodding of the head is a nonverbal language that functions to express the hearer's agreement the speaker's conveyed message. For example, "Apa kowe gelem mangan nangka?" or "Do you want to eat jackfruit?" If the hearer agrees to the speaker's question, he/she can answer "yes" by nodding his/her head. Saying "yes" can also be expressed through nodding one's head to indicate agreement. This is different from the shake of the head which functions to express the hearer's disagreement to the statement conveyed by the speaker. For example, "Kandhane mas Jarwo, jare kowe dhek wingi menyang Jakarta?" or "Jarwo said that you went to Jakarta a few days ago. Is that right?" The hearer may answer "Ora" or "No" by shaking his/her head to indicate negation to the speaker's statement. Even without saying "ora", shaking one's head is interpreted as rejecting [5]).

Eye-gaze is a sign that functions to pay attention to an object (person or object). When the speaker is standing face to face with the hearer, other objects attract attention. For example, the speaker is communicating with the hearer when suddenly someone passes by. Without ignoring the hearer, the speaker turns his gaze at the other objects. The speaker's gaze gives a sign or gesture to the hearer that the speaker agrees to what the hearer means or the speaker feels interested in the hearer.

Facial expression is an expression of the speaker's feelings to the hearer. A cheerful facial expression functions to signal that the person is pleased. For example, the speaker has just bought a new car or receives a gift; his son has just passed an exams, or just got a job, etc. Conversely, a sullen facial expression means that the speaker is not pleased with the hearer, or is disappointed with the turn of the event. For example, the speaker is disappointed with the hearer for not completing the job assigned to him, or the speaker hopes that the hearer does not repeat the same mistakes again. With such disappointments, the speaker is sullen.

Lip Movements is also one of nonverbal language. Men and women make different lip movements. When a man protrudes his lower lip while pulling back his upper lip, it means that the man is disappointed with what the hearer says. Meanwhile, when a woman's lower lip is spread forward, she sneers at her hearer. However, people's perceptions are sometimes different. 
There are lip movements that indicate attraction to the opposite sex. Some indicate disappointment and cynicism towards the hearer.

Hand movements and parts are also part or nonverbal language. Various hand movements, such as extending your hands forward with your palms down while motioning the fingers toward the speaker's body functions to beckon the hearer closer. Extending the hand with the palm down and then waving the fingers vigorously towards the hearer's body means shooing the hearer away. Embracing the hearer excitedly indicates that speaker feels they have a close relationship [5]. Folding the right hand elbow to the left and waving the palm of one's hand to the left indicates that the speaker is asking the hearer to move to the left of the speaker. Conversely, folding the elbow of the left hand to the right and clasping the palms of the hand together indicate the hearer to move to the left.

Finger movements can also be perceived differently. Touching the right or left index finger on the speaker's lips functions to signal that the hearer to be silent and not say a word. Straightening the little finger down, while folding the other finger hints that what the speaker says is of no importance. If the index finger is directed forward while being moved left and right, it means that the hearer must stop whatever he/she is doing.

Shaking hands indicates a close relationship and mutual respect. Nonetheless, shaking hands is graded. Tight handshake serves to state that the relationship between the speaker and the hearer is very close. In contrast, slight handshake (not tightly) serves to state that the speaker's relationship with the hearer is somewhat distant.

Body movements, though not very productive, are often carried out by the Javanese when communicating with others. Pulling the chest with both shoulders and holding palms straight open horizontally serves to show disagreement with the hearer's opinion. If the speaker sways the buttocks left and right while dancing, it indicates that the speaker is cheerfully dancing to the music.

Static nonverbal language is an immobile nonverbal language shown by the speaker's body parts which can be understood by the hearer based on the hearer's perception and the context of its use. Static nonverbal languages include the shape of the lips, the cheek, the tooth, the nose, the eyeball, the hair colour, the body posture, and the skin colour. Without movement, this static nonverbal language can be perceived by the hearers especially those with the Javanese cultural background.

The shape of the lips that the Javanese people favour is thin lips which are perceived as beautiful and charming for a woman. Thick lips create a negative impression because they are perceived as having no strong appeal.

The shape of a person's cheeks is usually round like "bakpau" (Chinese dumpling). The most favourable cheek is the one having "a pit" usually called "dimple". The dimpled cheek adds beauty to a woman's face or handsomeness to a man [2].

The shape of a person's teeth varies. Some are regular; some are irregularly large and small. However, the most favourable tooth shape is the shape of a tooth described metaphorically as "cucumber seeds", which the Javanese call it miji timun. Such a tooth shape can enhance a woman's appearance. For a woman, the shape of teeth where one of the canine teeth is protruding forward (gingsul) is also more favoured because it adds to the beauty of the woman's appearance. Conversely, for a man, the shape of the teeth, be they regular or irregular, is never an issue.

The shape of the nose for typical Javanese people is not too sharp-pointed; even many tend to be short (pug). However, having a sharp-pointed nose (both male and female) is perceived to have a good nose shape. The Javanese people consider the pointedness of the nose relative to 
the overall face shape. If the shape of nose does not match the shape of the face, it is usually not favoured.

There are various forms of Javanese eyeball. The round eyeballs are usually called "mbelalak" or "wide-eyed". There are also "rather narrow" eyes, and some are "slanted". The Javanese ideal shape of the eye is the "wide-eyed" which is perceived to show bravery (for men) or gracefulness (for women). The eye shape that Javanese also like is "rather narrow" because the person having such eyes can be perceived as having a delicate and gentle personality. Conversely, the "slanted" eyes are not favoured by men because they are perceived as lacking gentleness.

The shape and hair colour have a meaning also in nonverbal language. The typical shapes and hair colours of the Javanese people are "curly", "wavy", and "straight". Javanese men prefer women who have "wavy" hair. Women's wavy hair is described as "cascading" or ngandhanandhan. It is perceived to be an ideal shape of hair. Straight hair is also perceived as a good shape of hair as it gives a beautiful impression. However, "curly" hair shape is least favoured by the Javanese. Curly hair is perceived as wayward hair and gives the impression of a "chicken coop" (a chicken cage to lay eggs). The Javanese hair colour that is perceived as beautiful hair is pitch black. It is also perceived as a healthy hair colour. However, there is a shift of perception among younger generation. Young people dye their hair to look like westerners or Europeans. However, the blonde or brown colour is not the ideal hair colour favoured by the Javanese in general.

The body posture between Javanese men and women is perceived differently. The preferred Javanese body posture is a tall and stocky body posture without pot belly. A tall and stocky man is perceived as dashing and powerful. Conversely, a tall and hefty woman is not perceived positively because it gives an impression of a domineering woman. A woman's perception of an ideal body posture is a tall and slim posture (not thin). A tall, slender woman is perceived as being graceful and attractive.

The ideal colour of the skin (skin tone) perceived by the Javanese people is either "dark brown" skin tone (like a ripe sapodilla fruit) or "kuning nemu giring" (yellow like Curcuma heyneana Val.). The "dark brown" skin tone is perceived positively by Javanese men. Men having such skin tone will be perceived as dashing and powerful, while women with yellow skin tone are perceived as graceful. Black or white skin tone is not favoured by both Javanese men and women.

\section{CONCLUSIONS}

Based on the analysis and discussion above, nonverbal languages can be summarized as follows. First, nonverbal languages can be divided into two, namely static nonverbal languages and dynamic nonverbal languages. Dynamic nonverbal language is the nonverbal language of the body and parts of the body that are moved to convey the speaker's message to the hearer. Body and limb movements (kinesics) can send messages to hearers, such as (1) showing the speaker's attitude to the hearer, (2) describing the speaker's emotional condition to the hearer, and (3) controlling the environment so that the situation is conducive (regulatory), (4) affirming the speaker's wishes to the hearer, etc. Static nonverbal language can be in the form of speaker's body language, its parts, or objects.

Secondly, the form of dynamic nonverbal language can be a nod or shake of the head, eye gaze, facial expressions, lip movements, arm movements, finger movements, handshakes, body movements, etc. The static nonverbal language includes the shape of lips, cheek, nose, eyeball, hair color, body posture, etc. 
Third, the functions of nonverbal language for Javanese people vary, such as to express agreement (nodding) or rejection (shaking head, shrugging shoulders and pressing lips together), feeling pleased (cheerful facial expressions), to express disappointment (lower lip protruding), to silence (fingers sticking to the lips by looking at the partner), to indicate closeness of relationship (tight handshake), to show distant relations (slight handshake), etc. Conversely, nonverbal language functions are static, speakers cannot convey any functions. The function of static nonverbal language is precisely determined by the hearer's perception, which is very personal. For example, a person who has a sharp-pointed nose is perceived as handsome; a person with regular white teeth is perceived as good-looking; a dimpled cheek person is perceived as cute; black skin tone is perceived as dirty and shabby; brownish or whitish skin tone is perceived as clear and flawless skin, etc.

\section{REFERENCES}

[1] Miller R L 2005. Social Mobility in Europe. The British Journal of Sociology, 564 pp 665-666

[2] Pranowo 2017 Pengembangan Budaya Baca Melalui Strategi Metakognisi Membaca Pemahaman Bagi Mahasiswa. Prosiding KOLITA 15 pp 272

[3] Silvia B, Jane O'R, Sharon L O, and François C 2016 Nonverbal Behavior and Communication in the Workplace: A Review and an Agenda for Research. Journal of Management. 42 pp 1044-1074

[4] Pranowo 2009 Berbahasa Secara Santun (Yogyakarta: Pustaka Pelajar)

[5] Fergus M, Susan B, Ros B, and Jo K 2005 21st Century Social Work: Reducing ReOffending: Key Practice Skills (Edinburgh: The Scottish Executive)

[6] Jing W, Ronald J I, and Tonja R. N 2009 School Bullying Among Adolescents in the United States: Physical, Verbal, Relational, and Cyber. Journal of Adolescent Health 45 pp 368-375

[7] Koeswinarno 2015 Memahami Etnografi ala Spradley. Jurnal Studi Masyarakat, Religi, dan Tradisi. Balai Penelitian dan Pengembangan Agama Semarang 1 pp 257265

[8] James S 1997 Metode Etnografi (Yogyakarta: PT Tiara Wacana)

[9] Vivian C 1999 Going Beyond the Native Speaker in Language Teaching. TESOL Quarterly 332 pp 185-124.

[10] Henry G W 1989 Knowledge of Language and Ability for Use. Applied Linguistics 102 pp $128-137$

[11] Judee K B and David B B 1996 Interpersonal Deception Theory. Communication Theory 63 pp 311-328 